\title{
Anti-inflammatory Activity of Gumiganghwaltang through the Inhibition of Nuclear Factor- $K B$ Activation in Peritoneal Macrophages
}

\author{
Su-Jin Kim,${ }^{a, b}$ Hyun-Ja Jeong, ${ }^{a}$ Phil-Dong Moon, ${ }^{c}$ Kang-Min Lee, ${ }^{b}$ Hong-Beom LeE, ${ }^{a}$ \\ Hee-Jae Jung, ${ }^{a}$ Sung-Ki Jung, ${ }^{a}$ Hyung-Koo RheE, ${ }^{a}$ Deok-Chun YAng, ${ }^{d}$ \\ Seung-Heon HonG, ${ }^{c}$ and Hyung-Min $\mathrm{KIM}^{*}, a$ \\ ${ }^{a}$ College of Oriental Medicine, Kyung Hee University; 1 Hoegi-Dong, Dongdaemun-Gu, Seoul, 130-701, Republic of \\ Korea: ${ }^{b}$ Division of Biological Sciences, College of Natural Science, Chonbuk National University; Jeonju, Jeonbuk \\ 561-756, Republic of Korea: ${ }^{c}$ College of Pharmacy, Wonkwang University, Iksan, Jeonbuk 570-749, Republic of Korea: \\ and ${ }^{d}$ Department of Oriental Medicine Material and Processing, Kyung Hee University; Suwon 449-701, Republic of \\ Korea. $\quad$ Received July 20, 2004; accepted November 17, 2004
}

\begin{abstract}
Gumiganghwaltang (GMGHT) is an Oriental herbal prescription, which has been commonly used to treat a cold and inflammatory diseases in Korea. However, the mechanism of GMGHT is not clear. In this study, we investigated the anti-inflammatory mechanism of GMGHT in mouse peritoneal macrophages. GMGHT exerted an anti-inflammatory action through inhibiting lipopolysaccaride (LPS)-induced tumor necrosis factor (TNF)- $\alpha$ and interleukin (IL)-6 production in mouse peritoneal macrophages. The maximal inhibition rate of TNF- $\alpha$, and IL-6 production by GMGHT $(1 \mathrm{mg} / \mathrm{ml})$ was $52.31 \pm 2.8 \%$ and $56.31 \pm 3.1 \%$, respectively. In the inflammatory process, cyclooxygenase 2 (COX-2) and inducible nitric oxide synthase (iNOS) increased in peritoneal macrophages. GMGHT decreased the protein level of COX-2 and iNOS in LPS-stimulated mouse peritoneal macrophages. In addition, GMGHT inhibited nuclear factor- $\kappa B$ activation and $I \kappa B-\alpha$ degradation. Our study suggests that an important molecular mechanism by GMKHT reduce inflammation, which might explain its beneficial effect in the regulation of inflammatory reactions.
\end{abstract}

Key words Gumiganghwaltang; tumor necrosis factor- $\alpha$; interleukin-6; cyclooxygenase-2; inducible nitric oxide synthase; nuclear factor-kappa B

Gumiganghwaltang (GMGHT) consists of 9 different herbs and is a Korean herbal prescription, which has been commonly used to treat a cold and inflammatory diseases in Korea. However, it is still unclear how it regulates the immune or inflammatory responses.

Macrophage activation is known to play an important role in the inflammatory process ${ }^{1,2)}$ and produce potent proinflammatory cytokines such as tumor necrosis factor (TNF)- $\alpha$, and interleukin (IL)-6 which induce inflammation and recruit other immune cells, e.g., neutrophils and T lymphocytes. ${ }^{3)}$ Although these proinflammatory cytokines are beneficial to the host defense, they can also trigger pathological conditions when expressed in excess. ${ }^{4)}$ For example, massive stimulation of macrophages after a severe Gram-negative bacterial infection leads to excessive production of proinflammatory cytokines and the development of fatal septic shock syndrome, and multiple organ failure. ${ }^{4,5)}$ In addition, higher levels of proinflammatory cytokines are also implicated in a variety of chronic inflammatory diseases including rheumatoid arthritis, psoriasis, and Crohn's disease. ${ }^{4)}$

Nitric oxide (NO) produced by the inducible NO synthase $\left.(\mathrm{iNOS})^{6}\right)$ isoform is an essential component of the host innate immune and inflammatory response to a variety of pathogens, such as intracellular bacteria, viruses, fungi, and parasites. $^{7,8)}$ Nevertheless, as for other components of the host inflammatory and immune response, excessive activation of iNOS results in cardiovascular ${ }^{9}$ and organ dysfunction $^{6}$ in clinical ${ }^{10)}$ or experimental situations of inflammatory disease of both septic ${ }^{11)}$ and nonseptic ${ }^{12)}$ etiology.

Cyclooxygenases (COX) produce various types of prostaglandins (PGs), which are implicated in various physiological events including progression of inflammation, immunomodulation, and transmission of pain. ${ }^{13)}$ Two COX isoenzymes were identified: COX-1, the constitutive enzyme makes PGs that protect the stomach and kidney from damage and COX-2, the inducible enzyme induced by inflammatory stimuli such as cytokines produces PGs that contribute to the pain and swelling of inflammation. ${ }^{14-16)}$ We examined the effects of GMGHT on lipopolysaccaride (LPS)-induced cytokines (TNF- $\alpha$ and IL-6) production, COX-2, and iNOS protein expression from mouse peritoneal macrophages.

Nuclear factor-kappa B (NF- $\kappa$ B) plays a critical role in the expression of many genes involved in immune and inflammatory responses. ${ }^{17-19)}$ In unstimulated cells, Rel protein dimers, mainly p50 and p 65 subunits, are sequestered in the cytoplasm in complex with one of the several inhibitors of $\mathrm{NF}-\kappa \mathrm{B}$. The activation of NF- $\kappa \mathrm{B}$ is the consequence of phosphorylation of two specific serines near the $\mathrm{N}$ terminus of I $\kappa$ B- $\alpha$ and its degradation. The phosphorylation of $\mathrm{I} \kappa \mathrm{B}-\alpha$ lead to the ubiquitination, resulting in the degradation, which targets the protein for degradation by the $26 \mathrm{~S}$ proteasome and the translocation of NF- $\kappa \mathrm{B}$ to the nucleus. ${ }^{20)}$

The present study was designed to investigate whether GMGHT could modulate expression of cytokines (TNF- $\alpha$ and IL-6) and enzymes (COX-2 and iNOS) regulated by a transcription factor, NF- $\kappa \mathrm{B}$.

\section{MATERIALS AND METHODS}

Reagents Dulbeccos Modified Eagles Medium (DMEM) and LPS were purchased from Sigma (St. Louis, MO, U.S.A.). Rabbit polyclonal antibody (Ab) to iNOS was obtained from Transduction Laboratories (Lexington, KY, U.S.A.). Anti-mouse TNF- $\alpha$, biotinylated anti-mouse TNF- $\alpha$ and recombinant mouse TNF- $\alpha$ were purchased from R\&D Systems (Minneapolis, MN, U.S.A.). Anti-mouse IL-6, bi- 
otinylated anti- mouse IL-6 and recombinant mouse IL-6 were purchased from Pharmingen (San Diego, CA, U.S.A.). Thioglycollate (TG) was purchased from Difco Laboratories (Detroit, MI, U.S.A.). DMEM containing L-arginine (84 mg/l), Hanks balanced salt solution (HBSS), fetal bovine serum (FBS) and other tissue culture reagents were purchased from Life Technologies (Grand Island, NY, U.S.A.). Male C57BL/6 mice were purchased from Dae Han Experimental Animal Center (Eumsung, Republic of Korea).

Peritoneal Macrophage Cultures TG-elicited macrophages were harvested $3-4 \mathrm{~d}$ after i.p. injection of $2.5 \mathrm{ml}$ TG to the mice and isolated, as reported previously. ${ }^{21)}$ Using $8 \mathrm{ml}$ of HBSS containing $10 \mathrm{U} / \mathrm{ml}$ heparin, peritoneal lavage was performed. Then, the cells were distributed in DMEM, which was supplemented with $10 \%$ heat-inactivated FBS, in 4-well tissue culture plates $\left(2.5 \times 10^{5}\right.$ cells/well $)$ incubated for $3 \mathrm{~h}$ at $37^{\circ} \mathrm{C}$ in an atmosphere of $5 \% \mathrm{CO}_{2}$, washed three times with HBSS to remove non-adherent cells, and equilibrated with DMEM that contained 10\% FBS before treatment.

Preparation of GMGHT GMGHT which is a mixture of nine traditional drugs as shown in Table 1 was obtained from the Oriental drug store, Daehak Oriental Drugstore (Iksan, South Korea) and classified and identified by local experts. Extract of GMGHT was prepared by decocting the dried prescription of herbs with boiling distilled water. The extraction decocted for approximately $3 \mathrm{~h}$ has been filtered, lyophilized, and kept at $4{ }^{\circ} \mathrm{C}$. Dilutions were made in saline then filtered through $0.45-\mu \mathrm{m}$ syringe filter.

MTT Assay Cell viability was determined using MTT assay. Briefly, $500 \mu \mathrm{l}$ of peritoneal macrophage cells suspension $\left(3 \times 10^{5}\right.$ cells) was cultured in 4 -well plates for $24 \mathrm{~h}$ after treatment with various concentrations of GMKHT. $50 \mu \mathrm{l}$ of MTT solution $(5 \mathrm{mg} / \mathrm{ml})$ was added and then cells were incubated for $4 \mathrm{~h}$ at $37^{\circ} \mathrm{C}$. After washing the supernatant out, the insoluble formazan product was dissolved in DMSO. Then, optical density of 96-well culture plates was measured using enzyme-linked immunosorbent assay (ELISA) reader at $540 \mathrm{~nm}$. The optical density of formazan formed in untreated control cells was taken as $100 \%$ of viability.

Cytokines and Prostaglandins $\mathbf{E}_{2}\left(\mathrm{PGE}_{2}\right)$ Assay Cytokines assay was performed by a modified ELISA, as described previously. ${ }^{22}$ The ELISA was devised by coating 96well plates with mouse monoclonal Ab specific to TNF- $\alpha$, and IL-6. Before subsequent steps in the assay, coated plates were washed with PBS containing $0.05 \%$ Tween 20 . All reagents used in this assay were incubated for $2 \mathrm{~h}$ at $37^{\circ} \mathrm{C}$. Recombinant TNF- $\alpha$, and IL- 6 was diluted and used as a standard. Serial dilutions starting from $10 \mathrm{ng} / \mathrm{ml}$ were used to establish the standard curve. Assay plates were exposed sequentially to biotinylated mouse TNF- $\alpha$, and IL-6 avidin peroxidase, and ABTS substrate solution containing $30 \% \mathrm{H}_{2} \mathrm{O}_{2}$. The plates were read at $405 \mathrm{~nm}$. The $\mathrm{PGE}_{2}$ level was quantified by immunoassay kits according to the manufacture's protocols (Stressgen Biotechnologies, U.S.A.).

RT-PCR Analysis Total RNA was isolated from mouse peritoneal macrophage cells according to the manufacturers specification using easy-BLUE RNA extraction kit (iNtRON Biotech, Korea). The concentration of total RNA in the final elutes was determined by spectrophotometry. Total RNA $(2.5 \mu \mathrm{g})$ was heated at $65^{\circ} \mathrm{C}$ for $10 \mathrm{~min}$ and then chilled on ice. Each sample was reverse-transcribed to cDNA for
Table 1. The Ratio of the Component in GMGHT

\begin{tabular}{|c|c|c|}
\hline & Components & Ratio \\
\hline 1 . & Angelicae koreanae Radix (Angelica koreana MAx.) & 15 \\
\hline 2. & Saposhnikoviae Radix (Saposhnikovia divaricata ScHISKIN) & 15 \\
\hline 3. & Cnidii Rhizoma (Cnidium officinale MAKINO) & 12 \\
\hline 4. & $\begin{array}{l}\text { Angelicae Dahuricae Radix } \\
\text { (Angelica dahurica BENTHAM et HoOKER) }\end{array}$ & 12 \\
\hline 5 . & Atractylodis Rhizoma (Atractylodes lancea D.C ) & 12 \\
\hline 6. & Scutellariae Radix (Scutellaria baicalensis GEORGI) & 12 \\
\hline 7. & $\begin{array}{l}\text { Rehmanniae Radix (Rehmannia glutinosa LIBOsCHITZ } \\
\text { var. purpurea MAKINO) }\end{array}$ & 12 \\
\hline 8. & Asiasari Radix (Asiasarum sieboldi F. MAEKAWA) & 5 \\
\hline 9. & Glycyrrhizae Radix (Glycyrrhiza uralensis FISCHER) & 5 \\
\hline
\end{tabular}

$90 \mathrm{~min}$ at $37^{\circ} \mathrm{C}$ using cDNA synthesis kit (AmershamPharmacia, U.S.A.). PCR was performed with the following primers for mouse (m) TNF- $\alpha$ (5' ATG AGA ACA GAA AGC ATG ATC-3'; 5' TAC AGG CTT GTC ACT CGA ATT 3'), IL-6 (5' CGG GAT CCA TGT TCC CTA CTT CAC AA 3'; 5' CCC AAG CTT GGT TTG CCG AGT AGA-3'), COX-2 ( $5^{\prime}$ GGA GAG ACT ATC AAG ATA GTG ATC-3' ; 5' ATG GTC AGT AGA CTT TTA CGA CTA 3'), and GAPDH (5' GGC ATG GAC TGT GGT CAT GA 3'; 5' TTC ACC ACC ATG GAG AAG GC $3^{\prime}$ ) to verify if equal amounts of RNA were used for reverse transcription and PCR amplification from different experimental conditions. The annealing temperature was $55^{\circ} \mathrm{C}$ for $\mathrm{COX}-2,60^{\circ} \mathrm{C}$ for TNF- $\alpha, 50^{\circ} \mathrm{C}$ for IL- 6 and $62^{\circ} \mathrm{C}$ for GAPDH, respectively. Products were electrophoresed on a $1.5 \%$ agarose gel and visualized by staining with ethidium bromide.

Measurement of Nitrite (NO) Concentration Peritoneal macrophages $\left(3 \times 10^{5}\right.$ cells/well $)$ were pretreated with GMGHT for $30 \mathrm{~min}$, and then treated with LPS $(10 \mu \mathrm{g} / \mathrm{ml})$ for $48 \mathrm{~h}$. To measure nitrite, $100 \mu \mathrm{l}$ aliquots were removed from conditioned medium and incubated with an equal volume of Griess reagent (1\% sulfanilamidey/0.1\% $N$-(1-naphthyl)-ethylenediamine dihydrochloridey/2.5\% $\left.\mathrm{H}_{3} \mathrm{PO}_{4}\right)$ at room temperature for $10 \mathrm{~min}$. The absorbance at $540 \mathrm{~nm}$ was determined in a plate reader. $\mathrm{NO}_{2}^{-}$was determined using sodium nitrite as a standard. This value was determined in each experiment and subtracted from the value obtained from the medium with peritoneal macrophages.

Preparation of Cytoplasmic and Nuclear Extract $\mathrm{Nu}-$ clear and cytoplasmic extracts were prepared as described previously (Schoonbroodt et al., 2001). Briefly, after cell activation for the times indicated cells were washed with icecold phosphate-buffered saline (PBS) and resuspended in $60 \mu \mathrm{l}$ of buffer A $\left(10 \mathrm{~mm}\right.$ Hepes/KOH, $2 \mathrm{~mm} \mathrm{MgCl}_{2}, 0.1 \mathrm{~mm}$ EDTA, $10 \mathrm{~mm} \mathrm{KCl,} 1 \mathrm{~mm}$ DTT, and 0.5 mм PMSF, pH 7.9). The cells were allowed to swell on ice for $15 \mathrm{~min}$, lysed gently with $2.5 \mu \mathrm{l}$ of $10 \%$ Nonide P (NP)-40, and centrifuged at $2000 \mathrm{~g}$ for $10 \mathrm{~min}$ at $4{ }^{\circ} \mathrm{C}$. The supernatant was collected and used as the cytoplasmic extracts. The nuclei pellet was resuspended in $40 \mu \mathrm{l}$ of buffer B (50 mM HEPES/KOH, $50 \mathrm{~mm}$ $\mathrm{KCl}, 300 \mathrm{~mm} \mathrm{NaCl}, 0.1 \mathrm{~mm}$ EDTA, 10\% glycerol, 1 mм DTT, and $0.5 \mathrm{~mm}$ PMSF, $\mathrm{pH} 7.9$ ), left on ice for $20 \mathrm{~min}$, inverted and the nuclear debris was spun down at $15000 \boldsymbol{g}$ for $15 \mathrm{~min}$. The supernatant (nuclear extract) was collected, frozen in liquid nitrogen and stored at $-70^{\circ} \mathrm{C}$ until ready for analysis.

Western Blot Analysis Peritoneal macrophages $\left(5 \times 10^{6}\right.$ cells/well $)$ were stimulated with LPS $(10 \mu \mathrm{g} / \mathrm{ml})$. 
Whole cell lysates were made by boiling peritoneal macrophages in sample buffer $(62.5 \mathrm{~mm}$ Tris- $\mathrm{HCl}, \mathrm{pH} 6.8$, $2 \%$ sodium dodecyl sulfate (SDS), $20 \%$ glycerol, and $10 \% 2-$ mercaptoethanol). Proteins in the cell lysates were then separated by 7\% SDS-polyacrylamide gel electrophoresis and transferred to nitrocellulose paper. The membrane was then blocked with 5\% skim milk in PBS-tween-20 for $1 \mathrm{~h}$ at room temperature and then incubated with anti-COX-2, iNOS, NF$\kappa \mathrm{B}$, and $\mathrm{I} \kappa \mathrm{B}-\alpha$. After washing in PBS-tween-20 three times, the blot was incubated with secondary Ab for $1 \mathrm{~h}$ and the Abspecific proteins were visualized by the enhanced chemiluminesence detection system according to the recommended procedure (Amersham Corp. Newark).

Immunofluroescence The cells were washed with PBS, fixed with $3.7 \%$ paraformaldehyde for $30 \mathrm{~min}$, and cells were blocked with wash buffer containing 5\% BSA for $30 \mathrm{~min}$ and provided with $\mathrm{Ab}$, anti-NF- $\kappa \mathrm{B}$ at a 1:500 dilution (Santa Cruz Biotechnology, Inc.). After washing, cells were incubated with secondary $\mathrm{Ab}$ (Antirabbit, fluorescein isothiocyanate conjugated). After washing, cover-slips were placed. Slides were scanned under fluorescence with Olympus confocal microscope (New Hyde Park, NY).

Statistical Analysis The experiments shown are a summary of the data from at least-three experiments and are presented as the mean \pm S.E.M. Statistical evaluation of the results was performed by independent $t$-test.

\section{RESULTS}

Effects of GMGHT on Cytokine Production and mRNA Expression The effect of GMGHT was tested on TNF- $\alpha$ and IL-6 production from LPS-treated mouse peritoneal macrophages. As shown in Fig. 1A, TNF- $\alpha$ and IL-6 production in response to LPS was inhibited by pre-treatment with $0.01-1 \mathrm{mg} / \mathrm{ml}$ GMGHT in a dose-dependent manner, the maximal inhibition rate of TNF- $\alpha$ and IL- 6 production by GMGHT $(1 \mathrm{mg} / \mathrm{ml})$ was $52.31 \pm 2.8 \%$ and $56.31 \pm 3.1 \%$, respectively. Cell cytotoxicity by GMGHT was not observed (data not shown). To determine GMGHT can modulate LPSinduced TNF- $\alpha$ and IL-6 mRNA expression in peritoneal macrophages, RT-PCR was performed. Data in Fig. 1B, enhanced level of TNF- $\alpha$, and IL- 6 mRNA by stimulation of LPS was decreased by GMKHT in a dose-dependent manner

Effects of GMGHT on $\mathrm{PGE}_{2}$ production and COX-2 Expression To investigate the effect of GMGHT on LPSinduced $\mathrm{PGE}_{2}$ production, cells were pretreated with GMGHT $(0.01-1 \mathrm{mg} / \mathrm{ml})$ for $30 \mathrm{~min}$ and then treated with LPS for $24 \mathrm{~h}$. We showed that GMGHT decreased PGE2 production in dose-dependent manner (Fig. 2A). The maximal inhibition rate of $\mathrm{PGE}_{2}$ production by GMGHT $(1 \mathrm{mg} / \mathrm{ml})$ was $40.31 \pm 3.8 \%$.

To determine the effect of GMGHT on LPS-induced COX-2 expression in peritoneal macrophages, RT-PCR and western blotting were performed. As shown in Fig. 2B, treatment with LPS caused a significant increase of COX-2 mRNA expression. Pretreatment of GMGHT (0.01$1 \mathrm{mg} / \mathrm{ml}$ ) resulted in the inhibition of the COX-2 mRNA in a dose-dependent manner and expression of COX-2 protein was also inhibited compared to that of LPS treated cells (Fig. $2 \mathrm{C})$.

Effects of GMGHT on NO Production and iNOS Ex-

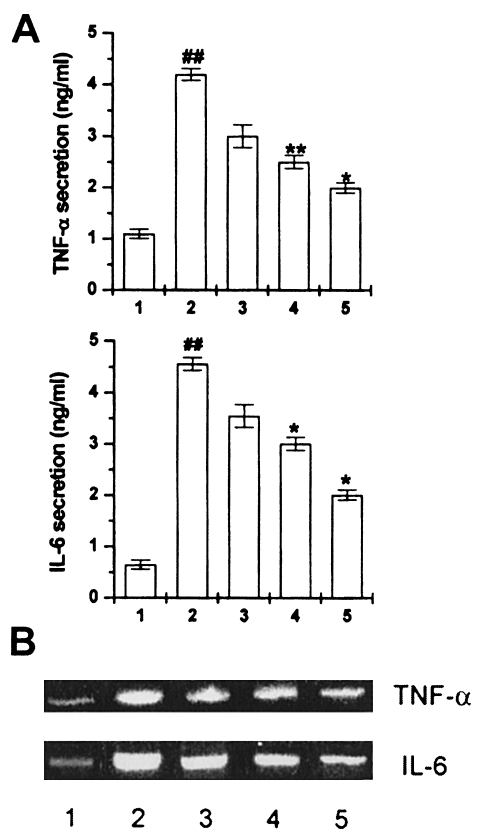

Fig. 1. Effect of GMGHT on Cytokine Production and mRNA Expression

Cells $\left(3 \times 10^{5} \mathrm{cells} / \mathrm{ml}\right)$ were pretreated with GMGHT $(0.01-1 \mathrm{mg} / \mathrm{ml})$ for $30 \mathrm{~min}$, and then stimulated with LPS $(10 \mu \mathrm{g} / \mathrm{ml})$ for $24 \mathrm{~h}$. Cytokine levels in supernatant were measured using ELISA (A). $3 \times 10^{6}$ cells were pretreated for $30 \mathrm{~min}$ with GMGHT $(0.01-1 \mathrm{mg} / \mathrm{ml})$ and followed by activation with LPS $(10 \mu \mathrm{g} / \mathrm{ml})$ for $6 \mathrm{~h}$, and then mRNA level was measured using RT-PCR. Products were electrophoresed on a $1.5 \%$ agarose gel and visualized by staining with ethidium bromide (B). 1, unstimulated cells; 2, LPS $(10 \mu \mathrm{g} / \mathrm{ml}) ; 3,0.01 \mathrm{mg} / \mathrm{ml}$ GMGHT plus LPS $(10 \mu \mathrm{g} / \mathrm{ml}) ; 4,0.1 \mathrm{mg} / \mathrm{ml}$ GMGHT plus LPS $(10 \mu \mathrm{g} / \mathrm{ml}) ; 5,1 \mathrm{mg} / \mathrm{ml}$ GMGHT plus LPS $(10 \mu \mathrm{g} / \mathrm{ml})$. All data represent the mean \pm S.E.M. of four independent experiments. \# $p<0.01$, significantly different from the unstimulated cells. $* *<0.05$, significantly different from the LPSstimulated cells. $* p<0.01$, significantly different from the LPS-stimulated cells.

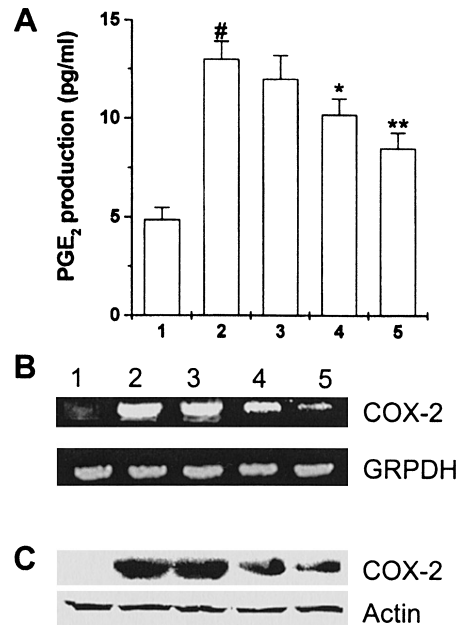

Fig. 2. Effects of GMGHT on $\mathrm{PGE}_{2}$ Production and COX-2 Expression

Cells $\left(3 \times 10^{5}\right.$ cells $\left./ \mathrm{ml}\right)$ were pretreated with GMGHT $(0.01-1 \mathrm{mg} / \mathrm{ml})$ for $30 \mathrm{~min}$, and then stimulated with LPS $(10 \mu \mathrm{g} / \mathrm{ml})$ for $24 \mathrm{~h}$. The amount of PGE $_{2}$ production was measured using immunoassay kits (A). Cells $\left(5 \times 10^{6} \mathrm{cells} / \mathrm{ml}\right)$ were pretreated with GMGHT $(0.01-1 \mathrm{mg} / \mathrm{ml})$ for $30 \mathrm{~min}$, and then stimulated with LPS $(10 \mu \mathrm{g} / \mathrm{ml})$ for $6 \mathrm{~h}$. Then, COX-2 mRNA level was assayed by RT-PCR (B). Cells $\left(5 \times 10^{6}\right.$ cells $\left./ \mathrm{ml}\right)$ were pretreated with GMGHT $(0.01-1 \mathrm{mg} / \mathrm{ml})$ for $30 \mathrm{~min}$, and then stimulated with LPS $(10 \mu \mathrm{g} / \mathrm{ml})$ for $24 \mathrm{~h}$. The protein extracts were assayed by western blot analysis for COX-2 (C). 1, unstimulated cells; 2, LPS (10 $\mu \mathrm{g} / \mathrm{ml}) ; 3,0.01 \mathrm{mg} / \mathrm{ml}$ GMGHT plus LPS $(10 \mu \mathrm{g} / \mathrm{ml}) ; 4,0.1 \mathrm{mg} / \mathrm{ml}$ GMGHT plus LPS $(10 \mu \mathrm{g} / \mathrm{ml}) ; 5,1 \mathrm{mg} / \mathrm{ml} \mathrm{GMGHT} \mathrm{plus} \mathrm{LPS}$ $(10 \mu \mathrm{g} / \mathrm{ml})$. All data represent the mean \pm S.E.M. of four independent experiments. $\# p<0.05$, significantly different from the unstimulated cells. $* * p<0.05$, significantly different from the LPS-stimulated cells. $* p<0.01$, significantly different from the LPSstimulated cells. 
pression To investigate effect of GMGHT on LPS-induced NO production, cells were pretreated with GMGHT $(0.01-$ $1 \mathrm{mg} / \mathrm{ml}$ ) for $30 \mathrm{~min}$ and then treated with LPS for $48 \mathrm{~h}$. We showed that GMGHT decreased NO production in dose-dependent manner (Fig. 3A). The maximal inhibition rate of NO production by GMGHT $(1 \mathrm{mg} / \mathrm{ml})$ was $59.11 \pm 3.1 \%$.

To determine the effect of GMGHT on LPS-induced iNOS expression in peritoneal macrophages, western blotting was performed. Data in Fig. 3B, treatment with LPS caused a significant increased of iNOS expression. Pretreatment of GMGHT $(0.01-1 \mathrm{mg} / \mathrm{ml})$ resulted inhibition of iNOS expression in a dose-dependent manner (Fig. 3B).

Effects of GMGHT on NF- $\boldsymbol{\kappa} \mathbf{B}$ Expression Since NF$\kappa \mathrm{B}$ activation requires nuclear translocation of Rel/p65 subunit of NF- $\kappa \mathrm{B}$, we examined the effect of GMGHT on the nucleus levels of Rel/p65 was examined after LPS-stimulation by western blot analysis. In LPS-stimulated cells, the expression level of Rel/p65 was increased. However, pretreatment of GMGHT decreased the expression level of Rel/p65 in dose- dependent manner (Fig. 3A). To confirm this result, nuclear translocation of p65 subunits of NF- $\kappa \mathrm{B}$ in mouse peritoneal macrophages was visualized using immunofluorescent confocal microscopy. Before LPS treatment, p65 was localized mainly in cytoplasm. After LPS treatment, there was extensive nuclear staining for the p65 protein. However, pretreatment with $1 \mathrm{mg} / \mathrm{ml}$ GMGHT inhibited LPS-stimulated translocation of Rel/p65 from to nuclear in mouse peritoneal macrophages (Fig. 3B).

Effect of GMGHT on I $\boldsymbol{\kappa}$ B- $\boldsymbol{\alpha}$ Degradation Most of the inhibitor of NF- $\kappa \mathrm{B}$ activation mediated their effect through suppressing I $\kappa \mathrm{B}-\alpha$ degradation. ${ }^{23)}$ To determine whether the inhibitory action of GMGHT was due to its effects on I $\kappa \mathrm{B}-\alpha$ degradation, the cytosol levels of $\mathrm{I} \kappa \mathrm{B}-\alpha$ was examined after LPS-stimulation by western blot analysis. As shown in Fig. 4 , we showed that LPS treatment effectively caused an induction of I $\kappa$ B- $\alpha$ degradation and that pretreatment of GMKHT $(1 \mathrm{mg} / \mathrm{ml})$ significantly inhibited LPS-induced I $\kappa \mathrm{B}-\alpha$ degradation in mouse peritoneal macrophages.

\section{DISCUSSION}

Proinflammatory cytokines such as TNF- $\alpha$ and IL-6 mediate the development of various inflammatory reactions. ${ }^{24,25)}$ In this study, we showed that GMGHT effectively inhibited the production and mRNA expression of TNF- $\alpha$, and IL- 6 cytokines on LPS-stimulated peritoneal macrophages. These results suggest that GMGHT might have an anti-inflammatory activity.

COX-2 plays a role in the pathophysiological processes including inflammation. ${ }^{26,27)}$ The present study showed that GMGHT effectively inhibited the mRNA and protein expression of COX-2 in a dose dependent manner. It suggests that GMGHT may provide its beneficial effect on anti-inflammation.

Although NO played an important role in the host defense against various pathogens, the overproduction of $\mathrm{NO}$ can be harmful and result in septic shock, rheumatoid arthritis, and autoimmune diseases. ${ }^{28)}$ Therefore, therapeutic agents that inhibit the iNOS may be useful for the relieving these inflammatory conditions. In this study, GMGHT inhibited iNOS expression in dose dependent manner. We suggest that the

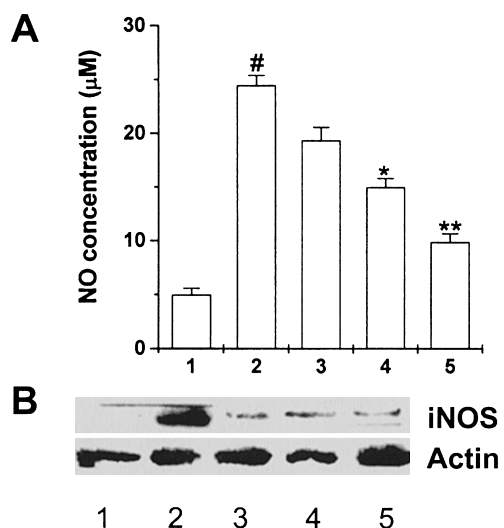

Fig. 3. Effects of GMGHT on NO Production and iNOS Expression

Cells $\left(3 \times 10^{5}\right.$ cells $\left./ \mathrm{ml}\right)$ were pretreated with GMGHT $(0.01-1 \mathrm{mg} / \mathrm{ml})$ for $30 \mathrm{~min}$, and then treated with LPS $(10 \mu \mathrm{g} / \mathrm{ml})$ for $48 \mathrm{~h}$. NO production in the medium was measured by the Griess reaction. The amount of NO production was quantitatively assessed using $\mathrm{NaNO}_{2}$ as a standard (A). Cells $\left(5 \times 10^{6} \mathrm{cell} / \mathrm{s} / \mathrm{ml}\right)$ were pretreated with GMGHT $(0.01-1 \mathrm{mg} / \mathrm{ml})$ for $30 \mathrm{~min}$, and then stimulated with LPS $(10 \mu \mathrm{g} / \mathrm{ml})$ for $24 \mathrm{~h}$. The protein extracts were assayed by western blot analysis for iNOS (B). 1, unstimulated cells; 2, LPS $(10 \mu \mathrm{g} / \mathrm{ml}) ; 3,0.01 \mathrm{mg} / \mathrm{ml}$ GMGHT plus LPS $(10 \mu \mathrm{g} / \mathrm{ml}) ; 4,0.1 \mathrm{mg} / \mathrm{ml}$ GMGHT plus LPS $(10 \mu \mathrm{g} / \mathrm{ml}) ; 5,1 \mathrm{mg} / \mathrm{ml}$ GMGHT plus LPS $(10 \mu \mathrm{g} / \mathrm{ml})$. All data represent the mean \pm S.E.M. of four independent experiments. ${ }^{*} p<0.05$, significantly different from the unstimulated cells. $* * p<0.05$, significantly different from the LPSstimulated cells. $* p<0.01$, significantly different from the LPS-stimulated cells.

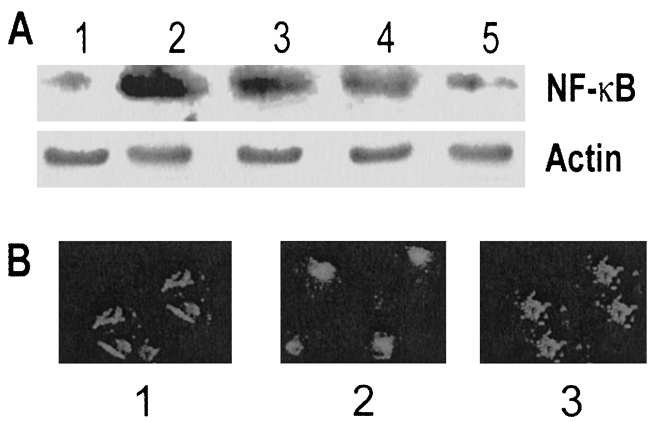

Fig. 4. Effect of GMGHT on Nuclear Translocation of the Rel/p65

Cells $\left(5 \times 10^{6}\right)$ were pretreated for $30 \mathrm{~min}$ with GMGHT $(0.01-1 \mathrm{mg} / \mathrm{ml})$ and then treated with LPS $(10 \mu \mathrm{g} / \mathrm{ml})$ for $1 \mathrm{~h}$. Nuclear extracts were prepared as described in Materials and Methods and determined for RelA/p65 by Western blot anlaysis (A). 1, unstimulated cells; 2, LPS $(10 \mu \mathrm{g} / \mathrm{ml}) ; 3,0.01 \mathrm{mg} / \mathrm{ml} \mathrm{GMGHT} \mathrm{plus} \mathrm{LPS}(10 \mu \mathrm{g} / \mathrm{ml}) ; 4$, $0.1 \mathrm{mg} / \mathrm{ml}$ GMGHT plus LPS $(10 \mu \mathrm{g} / \mathrm{ml}) ; 5,1 \mathrm{mg} / \mathrm{ml}$ GMGHT plus LPS $(10 \mu \mathrm{g} / \mathrm{ml})$ Cells $\left(3 \times 10^{5}\right)$ were preincubated with GMGHT $(0.01-1 \mathrm{mg} / \mathrm{ml})$ for $30 \mathrm{~min}$ and then treated with LPS $(10 \mu \mathrm{g} / \mathrm{ml})$ for $1 \mathrm{~h}$. Cells were fixed, stained, and analysed using confocal microscope (B). 1, unstimulated cells; 2, LPS (10 $\mu \mathrm{g} / \mathrm{ml})$; 3, GMGHT (1 mg/ml) plus LPS $(10 \mu \mathrm{g} / \mathrm{ml})$.

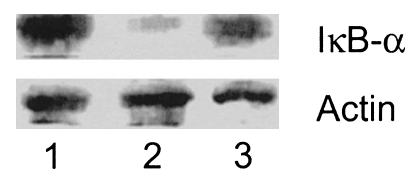

Fig. 5. Effect of GMGHT on I $\kappa \mathrm{B}-\alpha$ Degradation

Cells $\left(5 \times 10^{6}\right)$ were preincubated for $30 \mathrm{~min}$ with GMGHT $(0.01-1 \mathrm{mg} / \mathrm{ml})$ and then treated with LPS $(10 \mu \mathrm{g} / \mathrm{ml})$ for $1 \mathrm{~h}$. The cytosolic extracts were prepared as described in Materials and Methods and determined for I $\kappa$ B- $\alpha$ by Western blot anlaysis. 1, unstimulated cells; 2, LPS $(10 \mu \mathrm{g} / \mathrm{ml}) ; 3$, GMGHT $(1 \mathrm{mg} / \mathrm{ml})$ plus LPS $(10 \mu \mathrm{g} / \mathrm{ml})$.

anti-inflammatory action of GMGHT may be associated with the reduction of iNOS protein expression.

$\mathrm{NF}-\kappa \mathrm{B}$ is a transcription factor that is important for the activation of many inflammatory mediators, cytokines (e.g., TNF- $\alpha$ and IL-6), COX-2, and iNOS enzyme. ${ }^{29)}$ In inactivated state, $\mathrm{NF}-\kappa \mathrm{B}$ is sequestered in the cytoplasm bound to its inhibitory protein, $\mathrm{I} \kappa \mathrm{B}-\alpha$, which, with stimulation, is de- 
graded thus allowing NF- $\kappa \mathrm{B}$ to translocate into the nucleus and activate proinflammatory genes. ${ }^{23)}$ Degradation of $\mathrm{I} \kappa \mathrm{B}-\alpha$ is a key step for NF- $\kappa \mathrm{B}$-induced transcription of certain proinflammatory genes including inducible $\mathrm{COX}-2$ and iNOS. Other study reported that anti-inflammatory agents suppressed NF- $\kappa \mathrm{B}$ activation through stabilization of $\mathrm{I} \kappa \mathrm{B}-$ $\alpha .^{29,30)}$ In this study, GMGHT inhibited transcription factor, activation of NF- $\kappa \mathrm{B}$ by blocking the Rel/p65 translocation to the nucleus. Recent study demonstrated that aspirin activated NF $-\kappa \mathrm{B}$ by increasing the phosphorylation and degradation of $\mathrm{I} \kappa \mathrm{B}-\alpha$ in colon cancer cell lines, but had no effect on $\mathrm{I} \kappa \mathrm{B}-\alpha$ in embryonic kidney. ${ }^{31)}$ It is suggesting that the activation of $\mathrm{NF}-\kappa \mathrm{B}$ by aspirin is cell-type specific. GMGHT inhibited $\mathrm{NF}-\kappa \mathrm{B}$ activation through suppression of $\mathrm{I} \kappa \mathrm{B}-\alpha$ degradation and $\mathrm{Rel} / \mathrm{p} 65$ translocation in mouse peritoneal macrophages. Our results provide a novel mechanism by GMGHT regulate NF- $\kappa$ B activation in mouse peritoneal macrophages.

The promoter region of COX-2 contains two putative NF$\kappa \mathrm{B}$ binding sites. Thus, NF- $\kappa \mathrm{B}$ has been shown to be a positive regulator of COX-2 expression in murine macrophages exposed to LPS. Other research reported that serine protease inhibitor ( $N$ - $\alpha$ - $p$-tosyl-L-lysine chloromethylketone) which is inhibitors of NF- $\kappa \mathrm{B}$ activation inhibited the PGE2 production, and COX-2 expression. In this study, we suggested that COX-2 inhibitory mechanism of GMKHT is through suppression of $\mathrm{NF}-\kappa \mathrm{B}$ activation. ${ }^{32)}$

In conclusion, the anti-inflammatory activity of GMGHT in peritoneal macrophages could be was attributed at least in part to inhibition of the proinflammatory cytokines production, COX-2, and iNOS protein expression. These effects of GMGHT cause through the inhibition of LPS-induced NF$\kappa \mathrm{B}$ activation and $\mathrm{I} \kappa \mathrm{B}-\alpha$ degradation. These results may provide evidence for novel mechanism of the anti-inflammatory effect of GMGHT.

Acknowledgements This research was supported by a grant (\#PF 2-13) from Plant Diversity Research Center of 21st Century Frontier Research Program funded by Ministry of Science.

\section{REFERENCES}

1) Medzhitov R., Janeway C. A., Jr., Cell, 9, 295-298 (1997).

2) Beutler B., Curr. Opin. Immuno., 12, 20-26 (2000).

3) Medzhitov R., Janeway C. A., Jr., Curr. Opin. Immunol., 9, 4-9 (1997).
4) Beutler B., J. Invest. Med., 43, 227-235 (1995).

5) Parrillo J. E., N. Engl. J. Med., 328, 1471-1477 (1993).

6) Harbrecht B. G., Billiar T. R., Stadler J., Demetris A. J., Ochoa J. B., Curran R. D., Simmons R. L., Crit. Care Med., 20, 1568-1574 (1992).

7) MacMicking J., Xie Q. W., Nathan C., Annu. Rev. Immunol., 15, 323 350 (1997).

8) Pfeilschifter J., Muhl H., Eur. J. Pharmacol., 30, 237-245 (1999).

9) Weinberg J. B., Misukonis M. A., Shami P. J., Mason S. N., Sauls D. L., Smith G. K., McDonald B., Bachus K. E., Blood, 86, 1184-1195 (1995).

10) Petros A., Lamb G., Leone A., Moncada S., Bennett D., Vallance P., Cardiovasc. Res., 28, 34-39 (1994).

11) Vallance P., Moncada S., New Horiz., 1, 77-86 (1993).

12) Grosjean S. A., Arstall M. A., Mitchell R. N., Klappacher G. W., Kelly R. A., Pfeffer M. A., Pfeffer J. M., J. Card. Fail., 5, 236-245 (1999).

13) Vane J. R., Botting R. M., Inflamm. Res., 47, 578-587 (1998).

14) Morita I., Schindler M., Regier M. K., Otto J. C., Hori T., KeWitt D. L., Smith W. L., J. Biol. Chem., 270, 10902-10908 (1998).

15) Otta J. C., Smith, W. L., J. Lipid Mediat. Cell Signal., 12, 139-156 (1995).

16) Vane J. R., Bakhle Y. S., Botting R. M., Annu. Rev. Pharmacol. Toxicol., 38, 97-120 (1998).

17) Tegeder I., Pfeilschifter J., Geisslinger G., FASEB J., 15, 2057-2072 (2001).

18) Ghosh S., May M. J., Kopp E. B., Annu. Rev. Immunol., 16, 225-260 (1998).

19) Thanos D., Maniatis T., Cell, 80, 529-532 (1995).

20) Scherer D. C., Brockman J. A., Chen Z., Maniatis T., Ballard D. W., Proc. Natl. Acad. Sci. U.S.A., 92, 11259-11263 (1995).

21) Narumi S., Finke J. H., Hamilton T. A., J. Biol. Chem., 265, 70367041 (1990).

22) Kim M. S., Lim W. K., Cha J. G., An N. H., Yoo S. J., Park J. H., Kim H. M., Lee Y. M., Cancer Lett., 171, 79-85 (2001).

23) Ghosh S., May M. J., Kopp E. B., Annu. Rev. Immunol., 16, 225-260 (1998).

24) Dinarello C. A., Chest, 118, 503-508 (2000).

25) Stevens C., Walz G., Singaram C., Dig. Dis. Sci., 37, 818-826 (1992).

26) Crofford L. J., Oates J. C., McCune W. J., Gupta S., Kaplan M. J., Catella-Lawson F., Morrow J. D., McDonagh K. T., Schmaier A. H., Arthritis, Rheum., 43, 1891-1896 (2000).

27) Meade E. A., Smith W. L., DeWitt D. L., J. Biol. Chem., 268, 66106614 (1993).

28) Leiro J. M., Alvarez E., Arranz J. A., Cano E., Orallo F., Immunopharmacol., 4, 163-177 (2004).

29) Lappas M., Permezel M., Georgiou H. M., Rice G. E., Biol. Reprod., 67, 673-686 (2002).

30) Kopp E., Ghosh S., Science, 265, 956-959 (1994)

30) Yamamoto Y., Yin M. J., Lin K. M., Gaynor R. B., J. Biol. Chem., 274, 27307-27314 (1999).

31) Stark L. A., Din F. V. N., Zwacka R. M., Dunlop M. G., FASEB J., 15 1273 - 1275 (2001).

32) D'Acquisto F., Iuvone T., Rombola L., Sautebin L., Di Rosa M., Carnuccio R., FEBS Lett., 418, 175-178 (1997). 